\title{
KONSELING KREATIF DAN INOVASI DALAM PENELITIAN TINDAKAN BIDANG BIMBINGAN DAN KONSELING
}

\author{
SUKO BUDIONO
}

Email : mbahuko@yahoo.co.id

\begin{abstract}
ABSTRAK
Bagi guru pengakuan dan penghargaan di atas harus dijawab dengan meningkatkan profesionalisme dalam bekerja. Guru dan dosen mesti berefleksi mengenai hakekat berkarya di dunia pendidikan dengan tujuan mencerdaskan kehidupan masyarakat. Mengajar, menulis dan meneliti merupakan aktivitas utama ketika seseorang berkecimpung dalam tugas pendidikan dan pengajaran. Untuk mewujudkan hal tersebut guru $\mathrm{BK} /$ konselor harus dibekali dengan kemampuan meneliti, khususnya untuk guru BK/konselor adalah penelitian tindakan bidang bimbingan konseling (yang selanjutnya disebut PTBK). PTBK adalah penelitian mengenai suatu tindakan yang dilakukan pada sebuah kelas/tempat khusus dengan tujuan memperbaiki mutu layanan. Guru BK/konselor menginginkan terjadinya perbaikan, peningkatan, dan perubahan pelayanan yang lebih baik agar tujuan pelayanan dapat dicapai secara optimal. Penelitian ini dirancang khusus oleh guru BK/konselor untuk peningkatan kualitas layanan yang dilaksanakan di sekolah. Penelitian tindakan dalam BK lebih menjanjikan dampak langsung dalam bentuk (1) perbaikan dan peningkatan profesionalisme guru BK/konselor dalam memberikan layanan konseling; (2) implementasi berbagai program di sekolah dengan mengkaji berbagai indikator keberhasilan proses dan hasil layanan yang terjadi pada konseli dan keberhasilan proses dan implementasi berbagai program sekolah.
\end{abstract}

\section{PENDAHULUAN}

Guru BK/Konselor adalah sebuah profesi, untuk itu dalam pelaksanaan tugasnya Guru $\mathrm{BK} /$ Konselor harus profesional. Guru BK/Konselor adalah tenaga pendidik profesional yang telah menyelesaikan pendidikan akademik strata satu (S-1) program studi Bimbingan dan Konseling dan program Pendidikan Profesi Konselor dari perguruan tinggi penyelenggara program pengadaan tenaga kependidikan yang terakreditasi. Individu yang menerima layanan profesi bimbingan dan konseling disebut konseli.

Keberadaan Guru BK/Konselor dalam sistem pendidikan nasional dinyatakan sebagai salah satu kualifikasi pendidik, sejajar dengan kualifikasi guru, dosen, pamong belajar, tutor, widyaiswara, fasilitator dan instruktur (UU No. 20 Tahun 2003 Pasal 1 Ayat 6). Dengan penegasan bahwa pendidik adalah tenaga profesional memberikan makna bahwa pekerjaan yang diemban oleh pendidik adalah suatu profesi, maka pekerjaan sebagai konselor adalah juga suatu profesi.

Sebagai suatu profesi, pelaksanaan konseling mengandung tiga komponen trilogi profesi, yaitu komponen dasar keilmuan, komponen substansi profesi, dan komponen praktik. Dasarnya keilmuan profesi konseling adalah ilmu pendidikan, sedangkan substansi profesinya adalah substansi pelayanan konseling (Prayitno, 2007). Di dalam suatu profesi diidentifikasi ada tiga komponen yang secara langsung saling terkait, ketiganya harus ada, dan apabila salah satu atau lebih komponen itu tidak ada, maka profesi itu akan kehilangan eksistensinya. Ketiga komponen Trilogi Profesi adalah: (1) dasar keilmuan, (2) substansi profesi, dan (3) praktik profesi. Komponen dasar keilmuan menyiapkan (calon) tenaga profesional dengan landasan dan arah tentang wawasan, pengetahuan, keterampilan, nilai dan sikap (WPKNS) berkenaan dengan profesi yang dimaksud (Prayitno, 2007). Komponen substansi profesi memberikan modal tentang apa yang menjadi fokus dan objek praktik spesifik profesi dengan bidang khusus kajiannya, aspek-aspek kompetensi, sarana operasional dan manajemen, kode etik, serta landasan praktik operasinal. Komponen praktik merupakan realisasi pelaksanaan pelayanan profesi setelah kedua komponen profesi (dasar keilmuan dan subtansi profesi) dikuasai (Prayitno, 2007). 
Memperhatikan ketiga komponen Trilogi Profesi tersebut di atas, maka "profesi" tanpa dasar keilmuan yang tepat akan mewujudkan kegiatan "profesional" yang tanpa arah dan/atau bahkan malpraktik; tanpa substansi profesi yang jelas dan spesifik, suatu "profesi" itu akan kerdil, mandul dan dipertanyakan isi dan manfaatnya; dan tanpa praktik profesi, maka profesi menjadi tidak terwujud, dipertanyakan eksistensinya, dan tenaga "profesional" yang dimaksud tidak memiliki makna yang berati bagi kehidupan manusia. Untuk itu ketiga komponen trilogi profesi merupakan satu kesatuan tak terpisahkan; saling terkait, bermuara pada praktik profesi, terarah dan berlandaskan kaidah-kaidah keilmuan, dan berisi pelayanan sesuai dengan kebutuhan konseli dan masa depan individu mengacu pada kebahagiaan hidupnya.

Dari uraian ini jelas bahwa Guru BK/Konselor adalah pendidik, setara dengan jenisjenis pendidik lainnya, seperti guru, dosen, widyaiswara, dan lain-lain yang tentu saja dikenai oleh tugas-tugas fungsional berkenaan dengan kegiatan pendidikan pada umumnya. Tugas fungsional pokok dan mendasar bagi semua pendidik sebagaimana tercantum dalam aturan perundangan itu adalah kegiatan berkenaan dengan belajar dan pembelajaran, pembimbingan, pelatihan, penelitian dan pengabdian kepada masyarakat (khusus untuk pendidik di perguruan tinggi).

Setiap pendidik (seperti konselor, guru, dosen, widyaiswara) wajib melakukan berbagai kegiatan dalam melaksanakan tugas dan tanggung-jawabnya. Lingkup kegiatan konselor/guru tersebut meliputi (1) mengikuti pendidikan, (2) menangani proses pembelajaran, (3) melakukan kegiatan pengembangan profesi dan (4) melakukan kegiatan penunjang. Keputusan Menteri Negara Pendayagunaan Aparatur Negara dan Reformasi Birokrasi nomor 16/2009 penetapan jabatan fungsional guru dan angka kredit diatur dalam pasal-pasal diantaranya adalah bahwa untuk kenaikan jabatan/pangkat setingkat lebih tinggi dari Guru Pertama, pangkat Penata Muda, golongan ruang III/a sampai dengan Guru Utama, pangkat Pembina Utama, golongan ruang IV/e wajib melakukan kegiatan pengembangan keprofesian berkelanjutan yang meliputi sub unsur pengembangan diri, publikasi ilmiah, dan/atau karya inovatif.

\section{HASIL DAN PEMBAHASAN}

Konsep Dasar Penelitian Tindakan Bimbingan dan Konseling (PTBK)

Paradigma penelitian pendidikan secara umum sama dengan penelitian sosial, yaitu penelitian kuantitatif dan penelitian kualitatif. Penelitian kuantitatif secara sederhana diartikan sebagai penelitian data dalam bentuk angka-angka, sementara penelitian kualitatif data yang digunakan adalah data dalam bentuk bukan angka, yaitu berupa narasi, gambar dan lain-lain. Contoh penelitian kuantitatif antara lain penelitian survey, korelasional atau penelitian mengenai hubungan antar variabel independen $(\mathrm{x})$ dan variabel dependen $(\mathrm{y})$, perbandingan serta penelitian eksperimen. Contoh penelitian kualitatif antara lain adalah penelitian tindakan. Penelitian tindakan (action research) merupakan salah satu perspektif baru dalam penelitian pendidikan yang mencoba menjembatani antara praktik dan teori dalam bidang pendidikan (Dimyati, 2000). Action research merupakan studi mikro untuk membangun ekspresi konkrit dan praktis aspirasi perobahan di dunia sosial (pendidikan) untuk memperbaiki dan meningkatkan kualitas dan kinerja para praktisinya (Kemmis, dalam Supriadi;1998). Penamaan untuk penelitian tindakan berbeda-beda, seperti penelitian kelas (classroom research) karena penelitian ini tujuannya untuk perubahan perbaikan yang dilakukan di ruangan kelas (Hopkins, 1993).

Penelitian tindakan kelas (PTK) diperuntukkan bagi upaya memperbaiki kualitas proses dan hasil dari kegiatan belajar mengajar (KBM). Dengan demikian PTK terarah pada perbaikan kualitas tindakan guru dalam pelaksanaan tugas dan tanggung jawabnya sebagai guru, serta hasil yang dicapai siswa sesudah mengikuti belajar mengajar, permasalahan yang dibahas berkaitan dengan disain dan strategi pembelajaran, alat bantu, media dan sumber belajar, serta evaluasi pembelajaran. 
Penelitian tindakan dalam bimbingan konseling (Prayitno, 2007) analog dengan penelitian tindakan untuk guru kelas/bidang studi. Dengan demikian tindakan dalam PTBK dimaksudkan untuk memperbaiki kualitas proses pelayanan bimbingan konseling dan hasil yang diperoleh siswa sesudah mengikuti layanan konseling. Proses pelaksanaan PTBK sama dengan pelaksanaan penelitian tindakan (action research). Perbedaannya terletak pada bidang garapnya, yaitu masalah yang diangkat dalam layanan bimbingan dan konseling. Oleh karena itu pelaksanaan PTBK harus berdasarkan pada pelaksanaan penelitian tindakan (action research). Dalam setiap proses layanan konseling ditemukan berbagai masalah yang bemuara pada tidak mampunya siswa/konseli mandiri. Kualitas keprofesioanalan konselor, diantaranya diukur dari tingkat kemandirian konseli dalam mengambil keputusan dan kemampuan konselor bertindak memperbaiki proses layanan yang diberikannya di sekolah. Tindakan perbaikan tersebut mutlak adanya dan mungkin telah dilakukan oleh konselor dengan jalan bertanya kepada sejawat atau sesama konselor, bertanya kepada atasannya atau mengkaji pedomanpedoman yang sudah ada dalam program BK.

Pendekatan semacam ini disebut pendekatan otorita (Ibnu, 2000). Pendekatan ini menggunakan kemampuan pikiran untuk mencari penyelesaian yang logis dan konsisten dengan teori-teori pendidikan saat ini. Cara lain yang mungkin adalah mendasarkan pada pengalaman masa lalu, baik pengalaman sendiri atau pengalaman orang lain. Saat ini penting bagi konselor untuk menyelesaikan masalah-masalah yang dialami konseli ketika dia ingin memanfaatkan layanan konseling. Penelitian ini dikenal sebagai Penelitian tindakan bidang bimbingan konseling (PTBK). Penelitian ini merupakan suatu cara untuk menggabungkan teori dan praktik menjadi suatu kesatuan ide dalam praktik yang dilakukan konselor untuk memperoleh perspektif yang lebih luas (evidence-based practice) dalam rangka mengembangkan profesi konselor menuju profesi yang bermartabat.

Penelitian tindakan dalam BK lebih menjanjikan dampak langsung dalam bentuk (1) perbaikan dan peningkatan profesionalisme konselor dalam memberikan layanan konseling; (2) implementasi berbagai program di sekolah dengan mengkaji berbagai indikator keberhasilan proses dan hasil layanan yang terjadi pada konseli dan keberhasilan proses dan implementasi berbagai program sekolah (Prayitno, 2007). PTBK yang dilakukan oleh counselor-researcher berfungsi ganda, yaitu meningkatkan kualitas layanan konseling (as a counselor) dan berbagi pengalaman keberhasilannya dalam memecahkan masalah tersebut (as a researcher) melalui karya ilmiah inovatif layanan. Dengan berbagi pengalaman melalui jaringan PTBK itulah kualitas layanan di sekolah bisa bersama-sama meningkat.

Prosedur Pelaksanaan Penelitian Tindakan Bimbingan dan Konseling (PTBK)

Tahap pertama pelaksanaan penelitian tindakan bimbingan konseling (PTBK) dimulai dengan identifikasi masalah layanan yang ditemui konselor yang akan melakukan PTBK. Tidak ada konselor yang tidak memiliki masalah dalam memberikan layanan di sekolahnya. Masalah dalam memberikan layanan adalah situasi layanan dan atau hasil layanan yang masih dirasakan kurang, dan konselor ingin meningkatkan hasil layanannya. Konselor profesional selalu mencari cara untuk melaksanakan praktek layanan yang lebih baik dari yang sudah diusahakannya.Konselor yang profesional selalu melihat banyak masalah yang bisa diselesaikan untuk meningkatkan kualitas praktek layanannya. Tentunya tidak semua masalah akan diselesaikan sekaligus, beberapa masalah saja yang dipilih sebagai prioritas untuk diselesaikan lebih dulu. Masalah inilah yang diangkat sebagai dasar dalam melaksanakan PTBK. Setelah melakukan identifikasi masalah, berikut adalah mencari alternatif strategi layanan yang paling cocok untuk mengatasi masalah yang telah dipilih melalui kajian sumber pustaka atau diskusi dengan sejawat. Peneliti harus bisa menjelaskan bahwa strategi yang dipilih bisa menyelesaikan masalah yang akan dipecahkan. Ukuran terselesaikannya masalah melalui strategi yang dipilih itu nanti akan digunakan sebagai criteria of success, yang menentukan apakah strategi tersebut masih harus dimodifikasi lagi atau dianggap sudah baik. Strategi tersebut kemudian harus dirumuskan dalam skenario layanan yang berisi langkah- 
langkah layanan, dilengkapi dengan bahan dan media layanan yang relevan. Penyiapan strategi ini disebut dengan tahap perencanaan (tahap pertama).

Tahap kedua adalah mengimplementasikan skenario layanan yang telah disiapkan. Sebelum melaksanakan layanan, peneliti harus berlatih menguasai skenario layanan yang telah disiapkan sehingga pasa saat implementasi, kegiatan layanan sudah bisa diamati untuk melihat tingkat keberhasilannya. Apabila ternyata dalam pelaksanaan layanan, skenario layanan yang sudah disiapkan tidak diikuti dengan baik, maka layanan tersebut belum bisa diamati untuk di evaluasi tingkat keberhasilannya.

Tahap ketiga adalah pengamatan. Pada tahap ini kegiatan layanan seperti yang telah direncanakan sebelumnya diamati untuk dilihat tingkat keberhasilannya. Tujuan pengamatan adalah untuk mengumpulkan data yang menjadi indikator dampak dari implementasi starategi yang telah direncanakan, untuk menentukan seberapa jauh starategi yang diimplementasikan telah mampu menyelesaikan masalah seperti yang telah ditentukan dalam criteria of success. Data yang dikumpulkan pada tahap ini bukan yang terkait dengan indikator kesesuaian antara skenario layanan dengan pelaksanaan layanan, karena kesesuaian ini sudah harus dijamin tidak ada berbeda. Kalau masih ada perbedaan, maka pelaksanaan layanan belum bisa diamati, karena pengamatan hanya untuk melihat dampak dari strategi layanan yang telah sesuai denga skenarionya.

Tahap keempat adalah refleksi. Pada tahap ini data yang telah terkumpul pada tahap pengamatan dianalisis, untuk disimpulkan, kemudian dibandingkan dengan criteria of success telah tercapai, maka strategi tersebut telah terbukti mampu menyelesaikan masalah yang sedang dipecahkan. Penelitian dilanjutkan dengan melaporkan hasil penelitian dan menuliskannya secara lebih detail (sebagai panduan) bagi konselor lain bagaimana mengimplementasikan strategi tersebut ditempat lain yang memiliki masalah yang sama. Tetapi apabila target belum tercapai, peneliti harus mempelajari kembali strategi tersebut, untuk menentukan bagian mana dari starategi tersebut yang harus dimodifikasi, untuk diimplementasikan pada siklus berikutnya. Kemmis \&Taggart (1988) menjelaskan proses pelaksanaan penelitian tindakan bimbingan konseling (PTBK) bisa bersifat kolaboratif-partisipatoris yaitu adanya hubungan kemitraan secara kolaboratif antara peneliti sebagai konselor dengan konselor lain. Pelaksanaan tersebut dimulai dengan refleksi awal untuk mengidentifikasi permasalahan, kemudian secara berdaur ulang (1) menyusun perencanaan, (2) melakukan tindakan, (3) pengamatan, dan (4) refleks. Pelaksanaan penelitian dapat dilihat pada alur tindakan berikut:

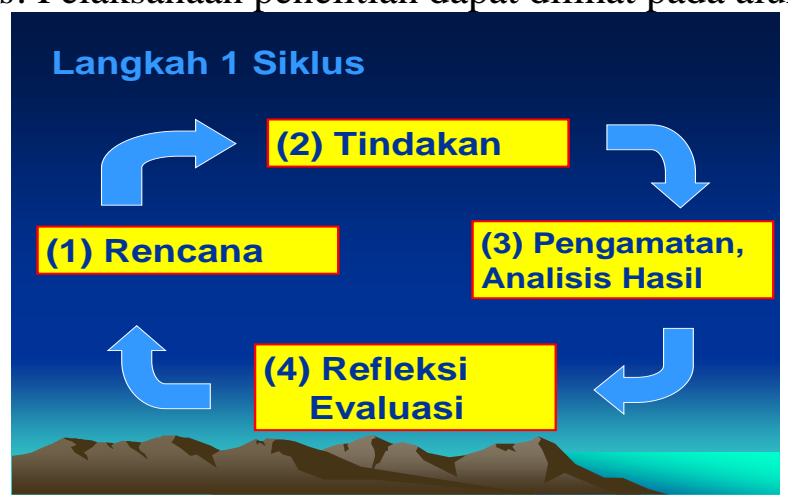

Gambar 1. Prosedur Pelaksanaan PTBK

Keempat tahapan dalam penelitian ini membentuk suatu siklus, diikuti siklus-siklus lain secara berkesinambungan membentuk seperti sebuah spiral. 


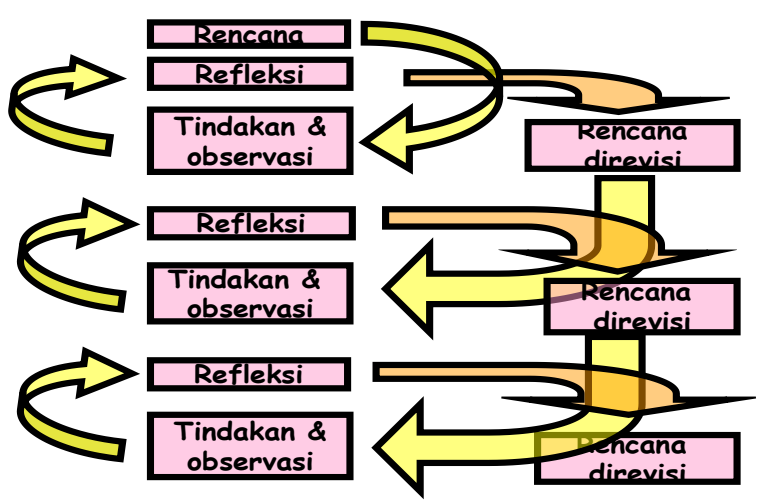

Gambar 2. Siklus PTBK

\section{Planning}

Planning adalah perencanaan strategi yang akan dikembangkan, akan direvisi, ditambah atau dikurangi, dan sebagainya, dan bukan laporan yang telah dilaksanakan. Perencanaan dalam PTBK berupa rincian kegiatan yang akan dilakukan konselor untuk meningkatkan, memperbaiki atau merubah suatu kondisi sesuai dengan masalah yang dimunculkan oleh konselor dalam pelaksanaan layanan yang diberikan pada konseli. Perencanaan tindakan merupakan formulasi pemecahan masalah dalam bentuk hipotesis tindakan (Depdiknas, 2004). Perencanaan dalam PTBK dimulai dari penentuan topik, misalnya "meningkatkan keberanian konseli mengemukakan pendapat". Agar masalah di atas dapat menjadi fokus dalam PTBK, konselor perlu menjadikan masalah ini lebih konkrit. Konselor perlu merencanakan tindakan yang bisa dicobakan untuk mengetahui apakah tindakan tersebut berpengaruh terhadap masalah utamanya. Secara khusus masalah di atas dapat dirumuskan sebagai berikut: "Apakah bimbingan kelompok dengan games yang berbasis kejujuran dapat meningkatkan keberanian konseli mengemukakan pendapat". Untuk membuat rumusan masalah konselor terlebih dahulu perlu memiliki inovasi untuk perubahan. Untuk melaporkan perubahan konselor merekam situasi atau keadaan sebelum dan sesudah perubahan

\section{Acting}

Pada tahap ini peneliti melaporkan cara kerja dalam mengimplementasikan strategi yang telah disiapkan. Strategi yang menjadi sentral permasalahan dalam PTBK berada dalam implementing, bukan planning. Ini bertentangan dengan alur prosedur PTBK, yaitu apabila satu siklus belum mencapai hasil yang ditargetkan,maka langkah berikutnya adalah memperbaiki planning (yang berisi skenario layanan konseling) bukan memperbaiki implementing. Kalau skenarionya berada dalam bagian implementing, berarti skenarionya tidak diperbaiki. Atau dengan kata lain kalau planning (yang berisi rencana akan menyusun skenario layanan) itu yang diperbaiki, berarti rencana akan menyusun itulah yang akan dirubah. Ini salah, karena yang akan direvisi adalah strateginya. Dalam tahap implementing cukup dideskripsikan secara sekilas bahwa semua kegiatan yang dilakukan pada tahap ini berdasarkan strategi yang telah disiapkan, perlu dijelaskan siapa pelaksana layanan, siapa observernya, bagaimana training yang telah dilakukan dapat menjamin bahwa strategi itu betul-betul telah dikuasai oleh implementer dan siap diamati tingkat keberhasilannya. Tidak ada lagi pertanyaan apakah implementernya sudah menguasai strateginya atau belum. Tidak relevan lagi pertanyaan seberapa jauh starategi yang telah disiapkan telah diikuti dalam proses implementasi karena semua ini sudah harus dikuasai, dilatihkan sebelum penelitian dimulai. Kalau dalam perjalanan ternyata implementasi belum sesuai dengan strategi yang telah disiapkan, maka pengamatan terhadap dampak keberhasilan belum bisa dilakukan. Penelitian harus diulang dari awal. 
Tahap observasi adalah kegiatan pengumpulan data. Dari hasil pengamatan yang dapat dilakukan sesuai dengan sifat datanya (kemampuan diamati dengan test, minat diamati dengan angket, suasana kelas diamati dengan merekam apa yang terjadi di kelas, dsb) akan digunakan sebagai bahan refleksi untuk menentukan apakah strategi yang telah diimplementasikan telah berhasil memecahkan masalah atau belum. Bukan untuk kepentingan lainnya. Jadi kalau diungkap dalam pertanyaan, maka peneliti pada saat melakukan pengamatan (pengumpulan data) bertanya seberapa jauh strategi yang sedang dan telah diimplementasikan tersebut telah berhasil memecahkan masalah yang sedang dicobakan? Sehingga data yang dikumpulkan adalah hal-hal yang terkait dengan dampak dari strategi yang diimplementasikan, bukan kegiatannya sendiri. Kegiatan konselor dalam mengimplementasikan strategi bukan data. Sering kali terjadi kesalahan, yaitu membuat checklist untuk kegiatan konselor dan konseli mengecek apakan strateginya telah dilaksanakan seperti yang telah diskenariokan atau belum. Jika data ini dikumpulkan maka data tersebut tidak bisa digunakan sebagai bahan refleksi untuk menilai strategi, karena data tersebut tidak berkaitan dengan ukuran keberhasilan strategi. Data tentang kegiatan konselor dan konseli cocok dipakai untuk memperbaiki implementasi, atau memperbaiki kemampuan konselor dalam mengimplementasikan strategi seperti dalam bimbingan praktek lapangan bimbingan dan konseling, PTBK bukan praktek bimbingan dan konseling, jadi beda tujuannya, dan berbeda pula data yang dikumpulkan untuk perbaikannya. Reflecting

Reflecting adalah tahapan analisis data untuk menentukan apakah criteria of success sudah tercapai atau belum. Dalam reflecting terkandung makna bahwa:

1) Data yang yang dikumpulkan melalui instrument observasi tentang pelaksanaan tindakan ditafsirkan, dicari eksplanasinya, kemudian dianalisis dan disentesis

2) Tahap untuk menentukan apakah tindakan sudah dapat mengatasi masalah atau belum, sehingga perlu tindak lanjut (siklus berikutnya).

3) Tahap ini penting dalam menentukan keberhasilan suatu penelitian karena dengan refleksi yang tajam dan terpercaya maka akan didapat suatu masukan berharga dan akurat bagi penentuan langkah tindakan selanjutnya.

4) Kadar ketajaman refleksi ditentukan oleh ketajaman dan keragaman instrumen observasi yang dipakai.

\section{Pendekatan Teknik Konseling Sebagai Alternatif Inovasi Dalam Layanan}

Konseling sebagai helping profesionals merupakan suatu ilmu yang didasarkan pada teori yang dikemukakan oleh sejumlah ahli. Teori tersebut dirumuskan berdasarkan dari pengalaman praktik terhadap konseli yang telah dikonselingi maupun melalui penelitian yang dilaksanakan selama bertahun-tahun (Prayitno, 1997). Lebih jauh dijelaskan bahwa guru pembimbing atau konselor yang akan melaksanakan konseling perlu mempelajari teori konseling agar terhindar dari praktek konseling yang prakmatik dan dokmatik. Di samping pemahaman guru pembimbing atau konselor terhadap teori konseling, pijakan sebagai suatu alternatif inovasi dalam layanan konseling, antara lain: (a) pendekatan konseling, (b) teknik konseling. Teknik konseling yang dapat menjadi pemahaman guru pembimbing atau konselor antara lain: dalam melakukan hubungan awal dalam konseling, teknik penjelajahan masalah, teknik intervensi masalah, dan teknik mengakhiri hubungan konseling.

\section{KESIMPULAN}

Dalam setiap proses layanan konseling ditemukan berbagai masalah yang bemuara pada tidak mampunya siswa/konseli mandiri. Kualitas keprofesioanalan konselor, diantaranya diukur dari tingkat kemandirian konseli dalam mengambil keputusan dan kemampuan konselor bertindak memperbaiki proses layanan yang diberikannya di sekolah. Tindakan perbaikan tersebut mutlak adanya dan mungkin telah dilakukan oleh konselor dengan jalan bertanya kepada sejawat atau sesama konselor, bertanya kepada atasannya atau mengkaji pedomanpedoman yang sudah ada dalam program BK. 
Saat ini penting bagi konselor untuk menyelesaikan masalah-masalah yang dialami konseli ketika dia ingin memanfaatkan layanan konseling. Penelitian ini dikenal sebagai Penelitian tindakan bidang bimbingan konseling (PTBK). Penelitian ini merupakan suatu cara untuk menggabungkan teori dan praktik menjadi suatu kesatuan ide dalam praktik yang dilakukan konselor untuk memperoleh perspektif yang lebih luas (evidence-based practice) dalam rangka mengembangkan profesi konselor menuju profesi yang bermartabat. Penelitian tindakan dalam BK lebih menjanjikan dampak langsung dalam bentuk (1) perbaikan dan peningkatan profesionalisme konselor dalam memberikan layanan konseling; (2) implementasi berbagai program di sekolah dengan mengkaji berbagai indikator keberhasilan proses dan hasil layanan yang terjadi pada konseli dan keberhasilan proses dan implementasi berbagai program sekolah. PTBK adalah penelitian mengenai suatu tindakan yang dilakukan pada sebuah kelas/ tempat khusus dengan tujuan memperbaiki mutu layanan. Guru pembimbing atau konselor menginginkan terjadinya perbaikan, peningkatan, dan perubahan pelayanan yang lebih baik agar tujuan pelayanan dapat dicapai secara optimal. Penelitian ini dirancang khusus oleh guru pembimbing atau konselor untuk peningkatan kualitas layanan yang dilaksanakan di sekolah.

\section{DAFTAR PUSTAKA}

Depdiknas Dirjen PMPTK. (2006). Karya Tulis Ilmiah dalam Pengembangan Profesi Guru: Macam, Kriteria, Prosedur Pengiriman dan Penilaian. Makalah dalam TOT PTK dan Penulisan Laporan sebagai Karya Tulis Ilmiah dalam Kegiatan Pengembangan Profesi Guru. Jakarta: Agustus 2006.

Depdiknas. (2004). Sains Penelitian Tindakan Kelas (PTK). Direktorat Jenderal Pendidikan Dasar dan Menengah Direktorat Pendidikan Lanjutan Pertama.

Dimyati. (2000). Belajar dan Pembelajaran. Jakarta : Rineka CiptaHopkins, 1993.

Ibnu. (2000). Dasar-dasar Metodologi Penelitian Kuantitatif Dalam Pendidikan. Jakarta. PT. Raja Grafindo Persada.

Kemmis \& McTaggart. (1988). The Action Research Planner.

Prayino. (2007). Penelitian Tindakan Bidang Bimbingan Konseling. Padang: Jurusan BK, FIP UNP

Prayitno, dkk. (1997). Seri Pemandu Pelaksanaan Bimbingan dan Konseling Di. Sekolah Buku III Pelayanan Bimbingan dan Konseling. Jakarta: Direktorat.

Supardi. (2005). Penyusunan Usulan, dan Laporan Penelitian PenelitianTindakan Kelas, Makalah disampaikan pada "Diklat Pengembangan Profesi Widyaiswara", Ditektorat

Tenaga Pendidik dan Kependidikan Dirjen Pendidikan Dasar dan Menengah, Departemen Pendidikan Nasional.

Undang-undang No. 20 tahun 2003 tentang Sistem Pendidikan Nasional 